monitored by a suitable technique to ensure that adequate blood levels are achieved.-We are, etc.,

H. R. INGHAM J. A. N. EMSLIE

Ayrshire Central Hospital, Irvine, Ayrshire

1 Mitchison, D. A., and Spicer, C. C., Fournal of General Microbiology, 1949, 3, 184.

Klein, J. O., Herschel, M., Therakan, R. M and Ingall, D., fournal of Infectious Diseases, $1971,124, S .224$.

McCracken, G. H., Chrane, D. F., and Thomas, M. L., ${ }_{124}$, Sour 214 .

Lorber, J., and Formby, D., Developmental Medicine and Child Neurology, 1968, 10,
Supplement, 16, 93.

\section{Australia Antigen and Pulmonary} Tuberculosis

SIR,-I was interested in the letter of $\mathrm{J}$. M. Martinez-V. and others (18 November, p. 427) concerning the incidence of Australia antigen in patients with pulmonary tuberculosis.

It would be interesting to know how these patients responded to antituberculosis therapy. In our experience patients who are carriers of Australia antigen tend to respond poorly to therapy, if their disease is extensive and if they are in the older age groups, as compared with patients with disease of similar extent who are not carriers. In two such patients sputum conversion could not be obtained in spite of all available acceptable drugs. - I am, etc.,

Merlin Park Hospital,

H. T. HITCHCOCK Galway, Eire

\section{How Infectious is Gonorrhoea?}

SIR,-The question posed by Dr. W. K Bernfeld (21 October, p. 173) and Dr. W. F. Felton (18 November, p. 431) is of great importance in view of the present epidemic incidence of gonorrhoea throughout the world. No doubt various factors influence the infectiousness of gonorrhoea but perhaps two are particularly significant.

Firstly, the individual who uses an antibiotic for any condition ar the time of sexual risk or during the incubation period will enjoy a large measure of protection unless the particular strain of gonococcus is unusually insensitive; such antibiotic treatment may be self-prescribed from the remainder left over from a supply given previously for other illness.

The second factor concerns the degree of sexual stimulation of the infected female. In women the gonococcus remains superficial and readily found on bacteriological investigation for only a short time after infection; it rapidly "digs in" in the deeper recesses of the mucous glands of the cervix and becomes superficial again only during menstruation or after sufficient sexual stimulation for the woman to approach or actually achieve orgasm. Given that both have gonorrhoea, "the enthusiastic amateur" may thus be more infectious than the prostitute with her numerous but entirely commercial consorts.-We are, etc.,

S. M. LAIRD

Royal Victoria Hospital,

R. B. ROY

Bournemouth

SIR,-When a male patient with proved gonorrhoea brings with him to the clinic his only female contact during the incubation period it seems reasonable to me to presume that she has gonorrhoea.

The fact that $I$ get a positive culture in less than half of such girls could be due to faulty technique, but would seem to be in line with the $22 \%$ infectivity to contacts found by Holmes and his co-workers 1 and quoted in Dr. W. F. Felton's letter (18 November, p. 431).-I am, etc.,

\section{R. N. R. GRANT}

Workington, Cumberland

1 Holmes, K. K., Johnson, D. W., and Trostle, U1. 170 . American foumal of Epidemiology, 1970 ,

\section{Diagnosis of Arterial Embolism}

SIR,-Mr. W. T. Morris is to be commended on his article on late embolectomy ( 9 September, p. 631). We cannot, however completely agree that in the many patients who have generalized atherosclerosis it is impossible to be sure whether arterial occlusion is due to embolism or atheroma. We take the opposite view that in many cases a confident diagnosis of arterial embolism may be made from the arteriographic features despite an indefinite clinical history. The radio logical features which we consider to be characteristic are an abrupt block in an artery, the upper end of which has a crescentic appearance with the convexity proximal, due, we believe, to the rounded upper end of the embolus itself. This is usually quite different from the irregular or tapering appearance of thrombotic occlusion.

This appearance of embolism we have now noted in over 20 patients with lower limb ischaemia on whom arteriography has been carried out and in patients who have undergone angiography and subsequent embolectomy up to three weeks after the onset of symptoms. ${ }^{1-W e}$ are, etc.,

J. W. ARDAGH The Princess Margaret Hospital,

Christchurch, New Zealand

1 Weston, T. S., Australasian Radiology, 1967, 11 , 354

\section{Oxygen Therapy}

SiR,-Your article on oxygen therapy, (25 November, p. 480) represents a much improved opinion over that expressed in 1968 under "Any Questions." I would, however, take issue with the complacent use of the term "uncontrolled oxygen therapy," which indeed does not take cognizance of the opinion expressed in one of your own leading articles advocating “.... inquiry into new ways of delivering to the patient known high concentrations of oxygen. For this there is a real need."2

It would be pedantic to repeat all the points which $I$ made in a letter to you in $1970,{ }^{3}$ so, on the basis of figures given in your article I would ask, rhetorically,-do prescribers take comfort in the fact that inspired oxygen tension may lie between 210 and $430 \mathrm{~mm} \mathrm{Hg}$ ? Further-do they mind that it may vary from breath to breath and patient to patient ${ }^{4}$ or even within a breath, so that the same device at the same flow rate may cause potential hypoxia in some patients and potential hyperoxia in others?

Anyone who has studied the history of oxygen therapy will realize that its use has always been attended by anomalies, ${ }^{5}$ which are no less excusable by their widespread or persistent practice. Across the board in therapeutics, there is no precedent for the dosage of a drug to be an unknown quantity. With a vital and potentially dangerous substance such as oxygen, dosage should surely be accurate whether at low or high concentration. The burden of proof lies more with those who claim that control of dosage is unnecessary rather than with those, like myself, who wish to introduce accuracy in dosage.

Lastly, two minor points. (1) The B.O.C. mask referred to is hardly "usually" used, enjoying a utilization approximately one twelfth of the M.C. and one seventeenth of the combined usage of the M.C., Edinburgh, and Harris masks, ${ }^{6}$ which are all similar. (2) The manufacturers recommend a flow of $41 . / \mathrm{min}$ for the $24 \%$ Ventimask, which gives a total flow of $961 . / \mathrm{min}$. - I am

Westminster Medical School

JULIAN M. LeIGH London S. $W .1$

1 British Medical Fournal, $1968,4,169$.

3 Leigh, J. M., British Medical Youmal, 1970,

5 Leigh, J. M., Anaesthesia, 1970, 25, 210. Surgeons of England. In press.

\section{Dysuria}

SiR,-We commonly ask our patients, "Does it sting when you pass water?" My photo shows a large wasps' nest which was found in an unopened box of disposable urinals. The insects had found a ready

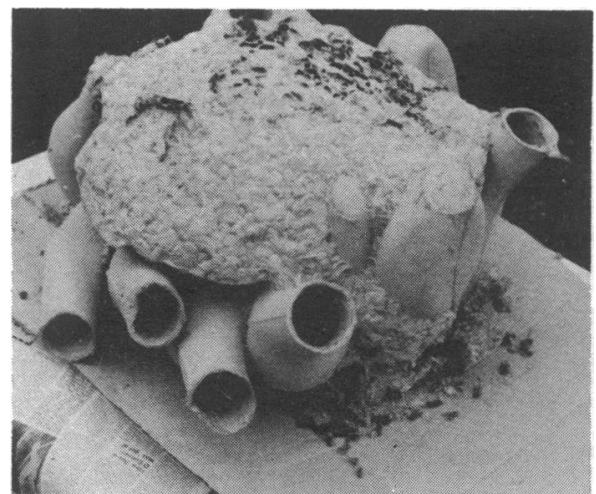

source of papier maché with which to make their cells and used many of the bottle openings to fly in and out.

Needless to say, none of the urinals were issued to patients.-I am, etc.

British Military Hospital,

A. B. L. Peare Hannover

\section{Scarred Heroes}

SIR,-A patient asked me to refer him to a surgeon for a vasectomy. When I said, "What do you need this for? You have been impotent for years," he replied, "If I don't have it done, my friends will suspect the truth."

I suppose that for a short period after 24 June 1902 people were proud of their appendicectomy scars. I remember, in the early days of the operation, one or two friends vainly displaying their leucotomy 